\title{
Deficiency of Carbonic Anhydrase in the
}

\section{Vasculature of Rabbit Kidneys}

\author{
R. M. Effros and S. Nioka, Division of Respiratory Physiology and Medicine, \\ Harbor-University of California at Los Angeles Medical Center, \\ Torrance, California 90509
}

\begin{abstract}
A B S T R A C T The transit of ${ }^{14} \mathrm{CO}_{2}$ and $\mathrm{H}^{14} \mathrm{CO}_{3}^{-}$through the renal vasculature was studied in rabbit kidneys perfused without erythrocytes and in an in vivo preparation in which erythrocytes were present. In the absence of erythrocytes, the transit of ${ }^{14} \mathrm{CO}_{2}$ from the renal artery to renal vein was much more rapid than that of $\mathrm{H}^{14} \mathrm{CO}_{3}^{-}$. This suggests that $(a)$ there is insufficient carbonic anhydrase (c.a.) in the vasculature between the renal artery and the exchange vessels of the kidney to ensure equilibration between $\mathrm{CO}_{2}$ and $\mathrm{HCO}_{3}^{-}$and $(b) \mathrm{CO}_{2}$ can diffuse directly between arterial and venous vessels in the kidney. Following infusions of carbonic anhydrase, the renal venous outflow patterns of ${ }^{14} \mathrm{CO}_{2}$ and $\mathrm{H}^{14} \mathrm{CO}_{3}^{-}$became the same in the perfused kidneys. Although the initial recovery of ${ }^{14} \mathrm{CO}_{2}$ remained greater than that of $\mathrm{H}^{14} \mathrm{CO}_{3}^{-}$after infusions of acetazolamide (a c.a. inhibitor), arteriovenous diff usion of ${ }^{14} \mathrm{CO}_{2}$ was diminished by this agent. This is attributed to inhibition of renal tubular c.a. The outflow patterns of $\mathrm{H}^{14} \mathrm{CO}_{3}^{-}$and ${ }^{14} \mathrm{CO}_{2}$ were nearly the same in the presence of erythrocytes, indicating that erythrocyte c.a. is sufficiently accessible to permit virtual equilibration of these radionuclides during the interval required for transit between the renal artery and exchange vessels. However, addition of carbonic anhydrase to the plasma seemed to accelerate transit of both ${ }^{14} \mathrm{CO}_{2}$ and $\mathrm{H}^{14} \mathrm{CO}_{3}^{-}$through the kidneys, and a small disequilibrium between $\mathrm{CO}_{2}$ and $\mathrm{HCO}_{3}^{-}$may therefore normally be present in the renal interstitium and capillaries.
\end{abstract}

\section{INTRODUCTION}

Evidence for endothelial carbonic anhydrase (c.a.) ${ }^{1}$ in the lung and leg has now been obtained by indicator

Received for publication 15 June 1981 and in revised form 13 December 1982.

${ }^{1}$ Abbreviations used in this paper: c.a., carbonic anhydrase. dilution procedures (1-5) and a variety of other physiological, histochemical, immunocytologic, and cytochemical procedures (6-12). This enzyme is associated with the same membranes that have angiotension converting enzyme activity and is apparently located on the outer surface of the endothelial cell. Endothelial c.a. is presumably more accessible to plasma bicarbonate than the erythrocyte enzyme, which seems to be strictly intracellular. Whitney and Briggle (13) have successfully isolated the endothelial enzyme from the lung and shown that it differs in molecular weight, composition, and activity from erythrocyte c.a. Synthesis of the enzyme by cultures of bovine pulmonary artery endothelial cells has also been documented (12).

Recently, DuBose et al. (14) suggested that there may be insufficient c.a. accessible to $\mathrm{HCO}_{3}^{-}$in the renal vessels or interstitium to ensure equilibration with $\mathrm{CO}_{2}$. Utilizing the same indicator dilution approach that demonstrated the presence of c.a. activity in the vessels of the lung and leg, we have obtained data indicating that there is not enough c.a. associated with the renal endothelium to ensure equilibration between ${ }^{14} \mathrm{CO}_{2}$ and $\mathrm{H}^{14} \mathrm{CO}_{3}^{-}$in the absence of erythrocytes. Equilibration was promoted by erythrocytes in the intact animal but may nevertheless be incomplete in the renal capillaries and/or interstitium.

\section{METHODS}

\section{General procedures}

In the initial in vitro studies, comparisons were made between the transit ${ }^{14} \mathrm{CO}_{2}$ and $\mathrm{H}^{14} \mathrm{CO}_{3}^{-}$from the renal artery to renal vein in kidneys perfused with artificial solutions not containing erythrocytes or c.a. The basic premise was that if the outflow patterns of $\mathrm{H}^{14} \mathrm{CO}_{3}^{-}$and ${ }^{14} \mathrm{CO}_{2}$ were different, then there is insufficient c.a. on the renal arterial and exchange vessels to ensure equilibration between these indicators. The effects of c.a. and acetazolamide upon transit of these indicators through the kidney were also determined. The studies were then repeated with an in vivo preparation in which the kidneys were perfused with erythrocytes to see 
if erythrocyte c.a. is sufficiently accessible to permit equilibration between ${ }^{14} \mathrm{CO}_{2}$ and $\mathrm{H}^{14} \mathrm{CO}_{3}^{-}$. An in vivo preparation was used to minimize hemolysis that might occur in kidneys artificially perfused with erythrocyte suspensions. Additional studies were conducted to determine the effect of acetazolamide upon extravascular $\mathrm{pH}$ in the in vitro kidney. The effect of injections and infusions of c.a. upon the exchange of equilibrated mixtures of ${ }^{14} \mathrm{CO}_{2}$ and $\mathrm{H}^{14} \mathrm{CO}_{3}^{-}$was investigated in the in vivo preparation.

The significance of differences between mean values were determined by analysis of variance with either repeated measures or randomized design (Tukey test).

\section{In vitro kidney studies}

Experimental preparations. 16 albino New Zealand rabbits weighing between 2.3 and $3.3 \mathrm{~kg}$ were injected with 12 $\mathrm{ml}$ of a $25-\mathrm{g} / \mathrm{dl}$ mannitol solution and $200 \mathrm{mg}$ of sodium heparin in an ear vein. 5 min later they were sacrificed with $150 \mathrm{mg}$ pentobarbital administered by the same route. The abdominal cavity was then opened and polyethylene catheters (PE 90) were placed in the renal artery and vein of the left or right kidney. A small catheter (PE 50) was inserted in the ureter. The kidney was removed and placed in a dish mounted in a $37^{\circ} \mathrm{C}$ bath (see Fig. 1). Blood was flushed from the kidney both before and after removal with several hundred milliliters of perfusion fluid. This served to lower c.a. levels in the renal venous outflow to $<0.0001$ of that in the rabbit blood cells (as determined by the Hodgen and Falk procedure) (15).

Perfusion solution. Each liter of the perfusion fluid contained $50 \mathrm{~g}$ bovine serum albumin (Cohn fraction V), 130 meq $\mathrm{Na}^{+}, 4$ meq K$, 1.5 \mathrm{mmol} \mathrm{Ca}^{2+}, 109 \mathrm{meq} \mathrm{Cl}^{-}, 25 \mathrm{meq}$ $\mathrm{HCO}_{3}^{-}, 28 \mathrm{meq}$ lactate, $1,500 \mathrm{mg}$ glucose, and 2,500 IU porcine heparin. The $\mathrm{pH}$ of this solution was adjusted to 7.4 at a $\mathrm{PCO}_{2}$ of 40 torr and a temperature of $37^{\circ} \mathrm{C}$ with small volumes of $2 \mathrm{~N} \mathrm{NaOH}$. The kidneys were perfused with this solution at $0.73 \pm 0.03(\mathrm{SD}) \mathrm{ml} / \mathrm{s}(0.061 \pm 0.015 \mathrm{ml} / \mathrm{s}$ per $\mathrm{g}$ of kidney $\mathrm{wt}$ ). The weight of the kidneys at the end of the experiments averaged $12.2 \pm 2.1$ (SD) g. Renal artery pressure averaged $139 \pm 20(\mathrm{SD})$ torr.

In many experiments, some leakage of fluid appeared to occur from small venous branches. This should not have altered the indicator outflow curves. Small amounts of fluid drained from the ureters in most experiments, but no attempt was made to analyze this fluid.

Injection solutions. The passage of $\mathrm{H}^{14} \mathrm{CO}_{3}^{-}$or ${ }^{14} \mathrm{CO}_{2}$ with each of the other indicators through the kidneys was studied in the following manner.

Simultaneous injections of $0.09 \mathrm{ml}$ of an alkaline solution and $0.09 \mathrm{ml}$ of an acid solution were made through a small T-tube into the renal arterial catheter within a 1-s interval. These solutions were adjusted so that when equal volumes were mixed, the $\mathrm{pH}$ of the solution would promptly become 7.4. In half of the runs, $\mathrm{NaH}^{14} \mathrm{CO}_{3}$ was included in the alkaline solution to yield $\mathrm{H}^{14} \mathrm{CO}_{3}^{-}$. In the other half, it was placed in the acid solution to produce ${ }^{14} \mathrm{CO}_{2}$. The acid solution contained $12 \mathrm{mM} \mathrm{HCl}$ in $0.1 \mathrm{~g} / \mathrm{dl}$ bovine serum albumin-saline solution and the alkaline solution contained 30 $\mathrm{mM}$ of the buffer Hepes in Ringer's lactate at pH 8.4. Hepes buffer was used rather than a $\mathrm{CO}_{2}-\mathrm{HCO}_{3}^{-}$system to ensure that a constant $\mathrm{pH}$ was rapidly attained. In contrast, equilibration of ${ }^{14} \mathrm{CO}_{2}$ and $\mathrm{H}^{14} \mathrm{CO}_{3}^{-}$proceeded slowly at the uncatalyzed rate in the absence of carbonic anhydrase. Because of the small dimensions of the injection catheter assembly, only $0.014 \mathrm{ml}$ of each solution remained in the injection tubing after injection and the delay from the point of injection to the renal artery averaged $0.05 \mathrm{~s}$.

Radioisotopes were added to the acid or alkaline injection solutions $\sim \mathrm{l}$ h before injection. Each injection contained 0.8 $\mu \mathrm{Ci}{ }^{125} \mathrm{I}$-albumin, and $5 \mu \mathrm{Ci}(121 \mathrm{nmol}) \mathrm{NaH}^{14} \mathrm{CO}_{3}^{-}$.

Measurements of extravascular $\mathrm{pH}$ were conducted with single injections of $0.09 \mathrm{ml}$ containing ${ }^{125} \mathrm{I}$-albumin, 0.22 $\mu \mathrm{Ci}$ of $\left[2-{ }^{14} \mathrm{C}\right] 5,5$-dimethyl-2,4-oxazolidine dione (DMO, 4 $\mathrm{nmol}$ ) and $4 \mu \mathrm{Ci}^{3} \mathrm{H}_{2} \mathrm{O}$.

Sample collection. Fluid was pumped at a rate just under that of the venous outflow through a side arm in the venous outflow catheter. The fluid was collected at 0.75 -s intervals into syringes mounted on an anaerobic collector (see Fig. 1). The venous outflow was augmented by an equal flow of saline to be sure there was sufficient fluid in each syringe to minimize dilution from the perfusion fluid placed in the dead space of these syringes. This was accomplished by ganging two identical Cole-Parmer peristaltic heads (Cole Parmer, Chicago, IL) on the collection pump. The delay between the renal vein and collection syringes averaged $2.5 \mathrm{~s}$. In the $\mathrm{pH}$ studies, the renal venous outflow was collected directly into cuvettes at 0.7-s intervals with an aerobic collector.

Sample measurements and data analysis. Aliquots of 0.2 $\mathrm{ml}$ were withdrawn from each syringe and delivered with $10 \mathrm{ml}$ of $15 \%$ phenethylamine in Aqueous Counting Scintillant (Amersham Corp., Arlington Heights, IL) into scintillation vials. Pure isotope standards and injection fluid standards were made in the perfusion fluid and processed in the same manner.

Gamma and beta activities were determined in multichannel, multiple sample counters. Corrections were made for crossover between channels and the radioactivities of each sample were divided by the amounts of each isotope injected to yield fractional concentrations (milliliters ${ }^{-1}$ ).

The fractional concentrations of each indicator were plotted against time as indicated in Figs. 2 and 3. The areas under each of these curves were calculated from the time of appearance to the peak of the ${ }^{125} \mathrm{I}$-albumin curves. The calculated areas were divided by those of ${ }^{125} \mathrm{I}$-albumin to yield the ratios, $R_{1}$. Values of $R_{1}$ were used to compare the initial recovery of each indicator relative to ${ }^{125} \mathrm{I}$-albumin in the venous outflow (see below). The total recovery of each indicator relative to that of ${ }^{125} \mathrm{I}$-albumin and the indicator mean transit times, $\bar{t}$, were calculated from the indicator dilution curves extrapolated on semilogarithmic coordinates as described previously (16). Renal blood flow was calculated from the area under the ${ }^{125} \mathrm{I}$-albumin curve. The mean transit times were corrected by subtracting the calculated delays between the point of injection and the renal artery and the renal vein and collection syringes. In order to compare indicator mean transit times between experiments, values were calculated for the ratios, $T$ :

$$
T=\left(\bar{t}_{14_{\mathrm{c}}}-\bar{t}_{125_{1}}\right) / \bar{t}_{125_{1}},
$$

where $t^{251}$ and $\bar{t}_{14 \mathrm{c}}$ indicate the corrected mean transit times of ${ }^{125} \mathrm{I}$-albumin and ${ }^{14} \mathrm{CO}_{2}$ or $\mathrm{H}^{14} \mathrm{CO}_{3}^{-}$.

The extravascular $\mathrm{pH}\left(\mathrm{pH}_{\mathrm{e}}\right)$ of the kidney was calculated from the perfusate $\mathrm{pH}\left(\mathrm{pH}_{\mathrm{p}}\right)$ and the mean transit times of ${ }^{125} \mathrm{I}$-albumin, $\left[{ }^{14} \mathrm{C}\right] \mathrm{DMO}$ and ${ }^{3} \mathrm{H}_{2} \mathrm{O}$ in the following manner: Values were calculated for $r$ from the mean transit times.

$$
r=\left(\bar{t}_{{ }^{14} \mathrm{C}_{\mathrm{CMMO}}}-\bar{t}_{125_{\mathrm{I}}}\right) /\left(\bar{t}_{\mathrm{H}_{\mathrm{H}_{\mathrm{O}} \mathrm{O}}}-\bar{t}_{125_{1}}\right) .
$$


IN VITRO

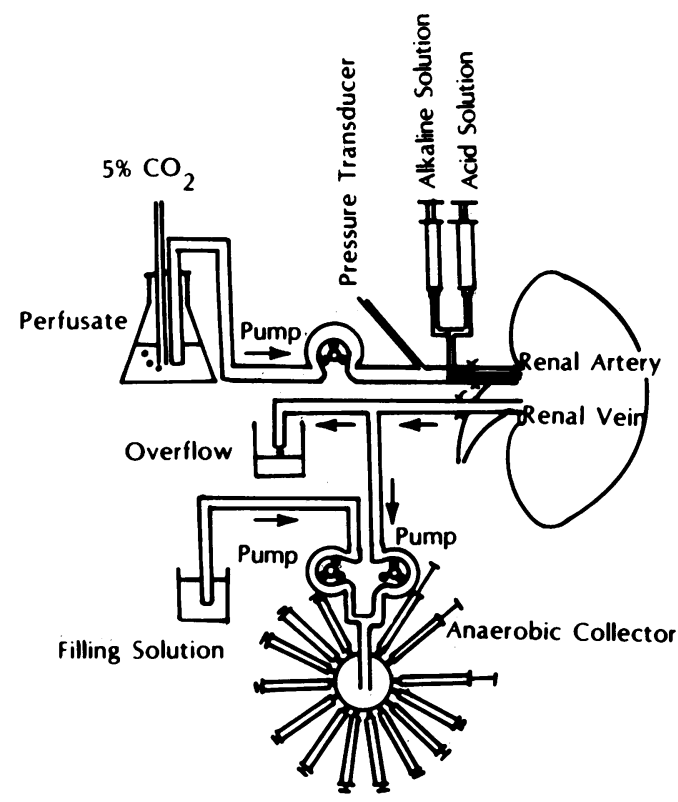

IN VIVO

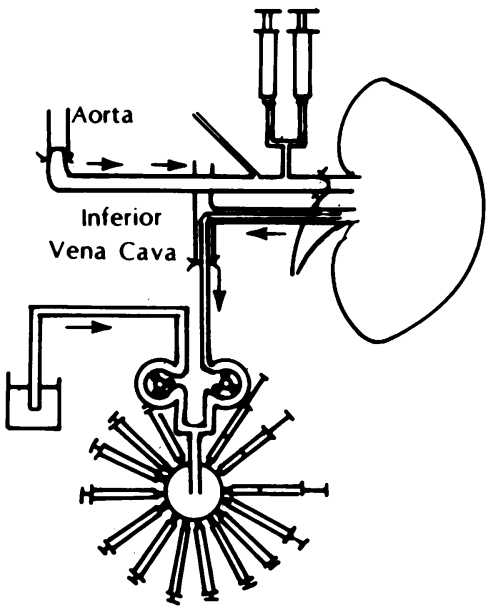

FigURE 1 Experimental procedures. In vitro studies: An isolated rabbit kidney was perfused at $37^{\circ}$ with an erythrocyte-free solution described in the text. Injections of $0.09 \mathrm{ml}$ of an alkaline solution and $0.09 \mathrm{ml}$ of an acid solution were administered simultaneously into a catheter in the renal artery line. By placing $\mathrm{H}^{14} \mathrm{CO}_{3}^{-}$in the acid solution, ${ }^{14} \mathrm{CO}_{2}$ was generated, whereas $\mathrm{H}^{14} \mathrm{CO}_{3}^{-}$was the principal ${ }^{14} \mathrm{C}$ indicator in the alkaline solution. ${ }^{125} \mathrm{I}$-albumin, was included in the solution as a reference vascular indicator. Fluid was collected from the outflow with a second pump into an anaerobic syringe collector at 0.75 -s intervals. To ensure that there was sufficient fluid in each syringe, the collected outflow was augmented by an equal flow of saline ("filling solution"). In vivo studies: The kidneys were perfused with blood flowing through a catheter connecting the aorta and renal artery. The indicators were injected through the renal artery catheter. Blood was pumped from a catheter that was inserted in the renal vein but did not obstruct it. This flow was diluted by an alkaline "filling" solution, which increased the volume of fluid in the collection syringes. The syringes were filled at 1 -s intervals.

The hydroxyl ion concentration of the extravascular compartment, $\left[\mathrm{OH}^{-}\right]_{e}$ was then calculated by solving the equation

$$
r=\frac{K_{\mathrm{b}}^{\prime}+\left[\mathrm{OH}^{-}\right]_{e}}{K_{\mathrm{b}}^{\prime}+\left[\mathrm{OH}^{-}\right]_{\mathrm{p}}}
$$

where $K_{\mathrm{b}}^{\prime}$ is the alkaline dissociation constant of DMO $(0.14$ $\left.\times 10^{-7} \mathrm{M}\right)$ and $\left[\mathrm{OH}^{-}\right]_{\mathrm{p}}$ is calculated from $\mathrm{pH}_{\mathrm{p}} \cdot \mathrm{pH}_{e}$ is then calculated from the equation

$$
\mathrm{pH}_{\mathrm{e}}=14+\log _{10}\left[\mathrm{OH}^{-}\right]_{\mathrm{e}} .
$$

These relationships are derived elsewhere (16-19). It was assumed that perfusate $\mathrm{pH}$ did not change significantly in transit through the kidney. (If any change did occur, it would suffice to assume that the magnitude of this change was unaltered by acetazolamide.)

Experimental protocols. In the first five experiments, the first two injections included alternatively either ${ }^{14} \mathrm{CO}_{2}$ or $\mathrm{H}^{14} \mathrm{CO}_{3}^{-}$, and ${ }^{125} \mathrm{I}$-albumin. For the third and fourth runs, the kidney was perfused for $5 \mathrm{~min}$ before injection and during the subsequent collection period with $200 \mathrm{mg} / \mathrm{liter}$ bovine erythrocyte c.a. (2,500 Wilbur-Anderson units/mg, Sigma Chemical Co., St. Louis, MO) in the same perfusion fluid. In the second set of five experiments, either 20 or $100 \mathrm{mg} /$ dl acetazolamide (Diamox, Lederle Laboratories, Pearl River, NY) was added to the perfusate in the third and fourth runs.

The $\mathrm{pH}$ of the perfusate was measured in the reservoir during the runs and did not change significantly in the c.a. runs $(\mathrm{pH}$ averaged $7.43 \pm 0.01 \mathrm{SD})$. A small rise in $\mathrm{pH}(0.03$ $\mathrm{U}$ ) occurred in the acetazolamide studies (control $\mathbf{p H}$ $=7.43 \pm 0.01 \mathrm{SD}$, acetazolamide $\mathrm{pH}=7.46 \pm 0.01 \mathrm{SD})$. To be sure that neither this difference nor the sequence of studies affected the data, an 11th study was performed in which $\mathrm{pH}$ was more closely regulated and acetazolamide was administered in the initial two runs. Following a 10-min flush with perfusate not containing acetazolamide, recontrol studies were obtained. The data closely resembled that found in the other five acetazolamide studies and the data of this experiment were not included in the statistical analysis.

In the five $\mathrm{pH}$ studies, control experiments were followed by infusions of acetazolamide. 


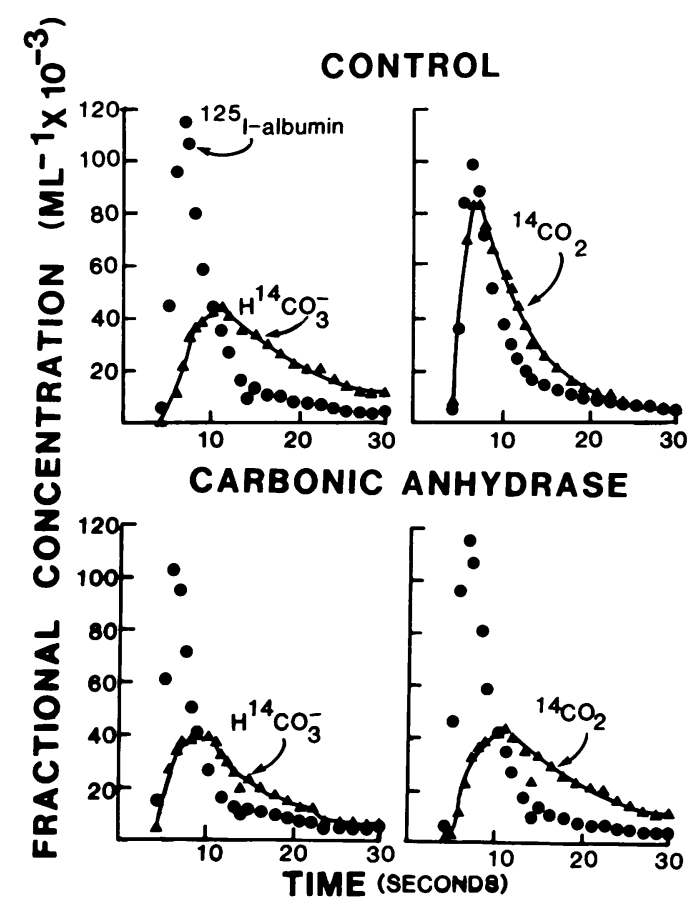

Figure 2 In vitro c.a. study. Fractional concentrations of radionuclides are plotted against time. Under control circumstances, the initial recovery of ${ }^{14} \mathrm{CO}_{2}$ compared with ${ }^{125} \mathrm{I}$ albumin exceeds that of $\mathrm{H}^{14} \mathrm{CO}_{3}^{-}$. The outflow patterns of these indicators become very similar when $200 \mathrm{mg} /$ liter c.a. is added to the perfusion fluid.

\section{In vivo kidney studies}

Experimental preparation. 27 albino New Zealand rabbits with average weights of $2.64 \pm 0.35$ (SD) $\mathrm{kg}$ were anesthetized with $8-12 \mathrm{ml}$ of a $10-\mathrm{mg} / \mathrm{ml}$ solution of sodium pentobarbital into an ear vein and a cannula was placed in the trachea. The animals were ventilated 30 times per minute with a tidal volume of $15-20 \mathrm{ml}$ of room air. The abdomen was then opened and catheters were placed in the right or left renal vein, renal artery, aorta, and ureter as shown in Fig. 1. Perfusion of the kidney was accomplished by connecting the aortic and renal artery catheters with a polyethylene tube that had a side arm. $60 \mathrm{ml}$ of $25 \mathrm{~g} / \mathrm{dl}$ mannitol and $2 \mathrm{ml}$ of a $1,000-\mathrm{U} / \mathrm{ml}$ solution of sodium heparinate were administered through the ear vein and $0.2 \mathrm{ml}$ of a $3-\mathrm{mg} / \mathrm{ml}$ papaverine hydrochloride solution was injected in an ear vein or the renal artery catheter. Urine flow remained low in these studies and was not collected. Kidney weight averaged $9.64 \pm 1.25$ (SD) $g$ at the end of the study.

Injection solutions. The injection solutions used for the double injection studies in the in vivo studies were the same as those used for the perfused kidneys. ${ }^{3} \mathrm{H}_{2} \mathrm{O}$ was included in the injection solutions of most of these experiments to provide a second reference curve to which the ${ }^{14} \mathrm{C}$ curves could be compared. In addition, six studies were conducted in which $0.09 \mathrm{ml}$ of a single solution containing an equilibrated mixture of $\mathrm{H}^{14} \mathrm{CO}_{3}^{-}$and ${ }^{14} \mathrm{CO}_{2}$ at $\mathrm{pH} 7.4$ was injected into the renal artery.

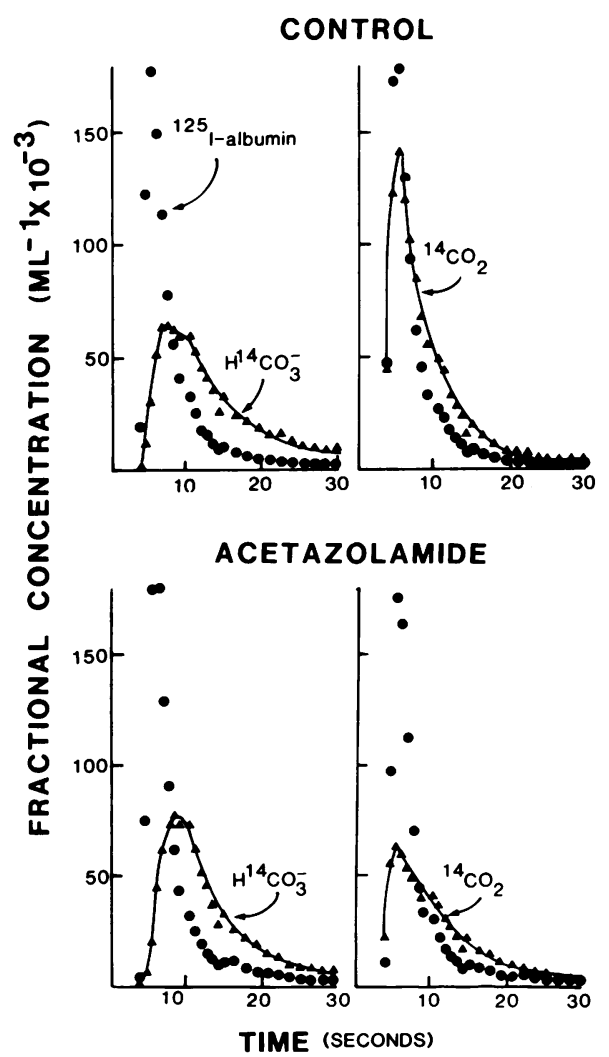

Figure 3 In vitro acetazolamide study. Perfusion of the kidney with $100 \mathrm{mg} /$ liter acetazolamide significantly decreases initial recovery of ${ }^{14} \mathrm{CO}_{2}$ but the unslope and peak remains skewed to earlier times than those of $\mathrm{H}^{14} \mathrm{CO}_{3}^{-}$.

Sample collections. Fluid was pumped from the renal venous catheter at $3.85 \mathrm{ml} / \mathrm{min}$ with a peristaltic pump into syringes mounted on an anaerobic collector. Each syringe was filled for $1 \mathrm{~s}$. The outflow (Fig. 1) was diluted with a flow of $13.0 \mathrm{ml} / \mathrm{min}$ of an alkaline trapping solution: 0.03 $M$ of the buffer tris (hydroxymethyl) aminomethane (Calbiochem, Behring Corp., Div. American Hoechst Corp., La Jolla, CA) in normal saline at pH 8.4. This was accomplished by ganging together a model 7014 and a model 7013 head on a Cole Parmer peristaltic pump. Augmenting flow in this fashion permitted collection of enough fluid in the syringes to minimize dilution by fluid in the dead space of these syringes. The mean delay between the renal vein and collection syringes was $9.8 \mathrm{~s}$.

Sample measurements and analysis. To minimize quenching, small volumes $(0.05 \mathrm{ml})$ of the collected samples were added to $10 \mathrm{ml}$ of $15 \%$ phenethylamine. The ratio of the area under the ${ }^{14} \mathrm{C}$ curve to that of the ${ }^{125} \mathrm{I}$-curve was calculated as described above. A comparable ratio, $R_{H}$, of ${ }^{14} \mathrm{C}$ area to ${ }^{3} \mathrm{H}_{2} \mathrm{O}$ area (up to the time that the peak of the ${ }^{125}$ I curve was reached) was also calculated in those experiments in which ${ }^{3} \mathrm{H}_{2} \mathrm{O}$ was included in the injection bolus. It was reasoned that the outflow patterns of neither ${ }^{125} \mathrm{I}-\mathrm{al}$ bumin nor ${ }^{3} \mathrm{H}_{2} \mathrm{O}$ would be influenced by whether ${ }^{14} \mathrm{CO}_{2}$ or $\mathrm{H}^{14} \mathrm{CO}_{3}^{-}$injections were made because this distinction was 

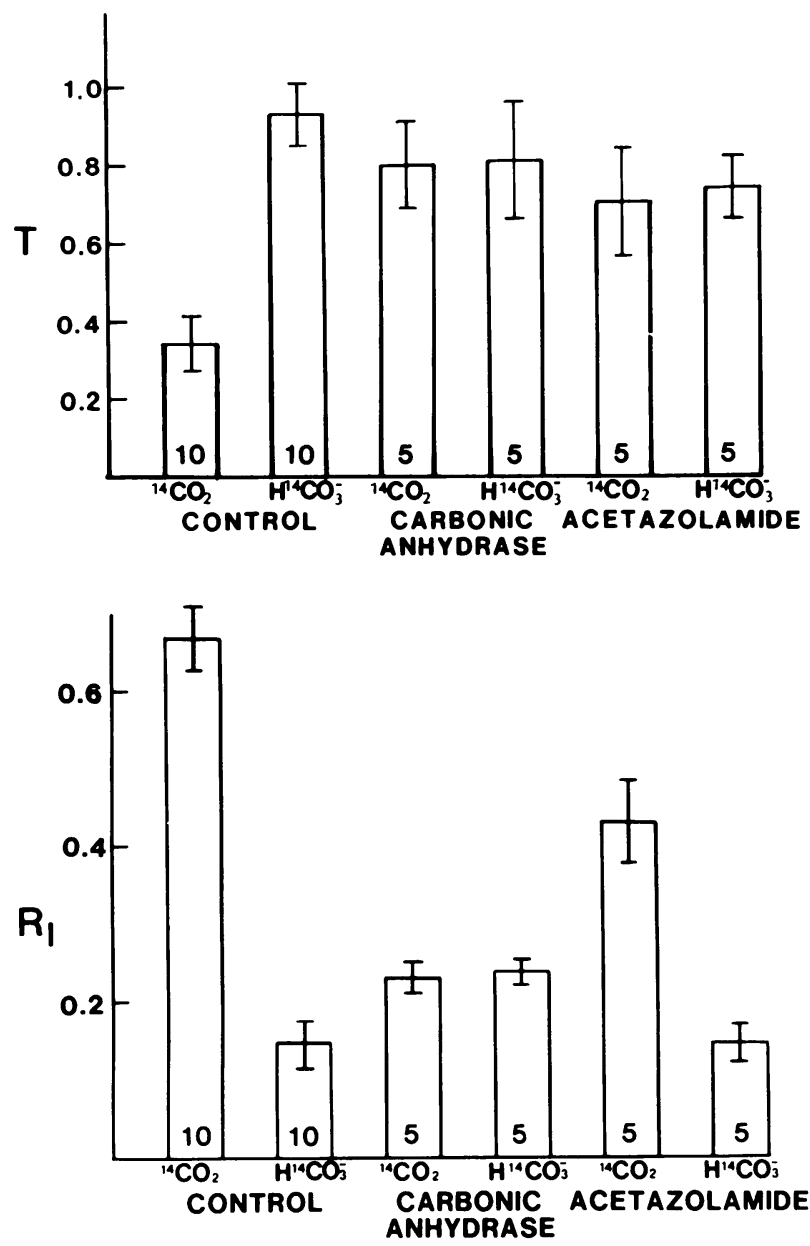

Figure 4 Summary of in vitro studies. Mean values of $\boldsymbol{R}_{1}$ and $R_{H}$ are indicated with standard errors. Note significant differences of $R_{1}$ and $T$ values between control ${ }^{14} \mathrm{CO}_{2}$ and $\mathrm{H}^{14} \mathrm{CO}_{3}^{-}$studies $(P<0.01)$. Following infusions of c.a., the outflow parameters of ${ }^{14} \mathrm{CO}_{2}$ and $\mathrm{H}^{14} \mathrm{CO}_{3}^{-}$became very similar with a decrease in $R_{1}$ of ${ }^{14} \mathrm{CO}_{2}$ and an increase in $T$ of ${ }^{14} \mathrm{CO}_{2}$ $(P<0.01)$. After acetazolamide, $R_{1}$ of ${ }^{14} \mathrm{CO}_{2}$ decreased but remained greater than $R_{1}$ of $\mathrm{H}^{14} \mathrm{CO}_{3}^{-}(P<0.01)$. T values became the same after acetazolamide.

simply based upon whether the indicators were placed in the acid or alkaline solutions. Experimental interventions such as infusions or injections of c.a. or inhibitors could alter the outflow patterns of ${ }^{125} \mathrm{I}$-albumin or ${ }^{3} \mathrm{H}_{2} \mathrm{O}$ by changing renal blood flow. No significant effect upon renal blood flow was observed (see below). One advantage of using the ${ }^{3} \mathrm{H}$ curve as a reference for ${ }^{14} \mathrm{C}$ is the rather close proximity of these curves, which seemed to permit detection of smaller changes in the ${ }^{14} \mathrm{C}$ outflow patterns. Because they are washed out of the organ during comparable intervals, small variations of flow would be expected to have similar effects on the outflow concentrations of each. As indicated below, significant differences in $\boldsymbol{R}_{H}$ were observed in the control experiments and those with single injections of equilibrated
${ }^{14} \mathrm{CO}_{2}-\mathrm{H}^{14} \mathrm{CO}_{3}^{-}$, whereas no significant differences in $R_{1}$ were observed in these studies. This may indicate that use of $\boldsymbol{R}_{H}$ provided a more sensitive parameter of change.

Recirculation of indicators in these in vivo experiments obscured the later portions of the outflow curves. This problem was particularly troublesome for the ${ }^{14} \mathrm{C}$ and ${ }^{3} \mathrm{H}$ curves, which are relatively prolonged. Monoexponential extrapolations of the ${ }^{125} \mathrm{I}$-albumin curves were used for calculations of blood flow. Comparable extrapolations of the ${ }^{14} \mathrm{C}$ and ${ }^{3} \mathrm{H}$ curves were not sufficiently reliable to permit mean transit time calculations.

Experimental protocols. The double injection procedure was used in each of the first two studies. In the first study (Figs. 5 and 6), ${ }^{14} \mathrm{CO}_{2}$ and $\mathrm{H}^{14} \mathrm{CO}_{3}$ were injected alternately into the renal artery catheter with ${ }^{125} \mathrm{I}$-albumin. Thereafter $50 \mathrm{mg} / \mathrm{kg}$ acetazolamide (Lederle Laboratories), an inhibitor of c.a., was injected intravenously and the renal artery injections were repeated.

In the second study (Fig. 7), the control studies were followed by intravenous injections of $25 \mathrm{mg} / \mathrm{kg}$ of bovine erythrocyte c.a. $(2,700$ Wilbur-Anderson units/mg, Sigma Chemical Co.) that were given $5 \mathrm{~min}$ before each injection of the radioactive solutions.

In a third study (Fig. 9), a single injection containing a mixture of $5 \%{ }^{14} \mathrm{CO}_{2}$ and $95 \% \mathrm{H}^{14} \mathrm{CO}_{3}^{-}(0.03 \mathrm{mM}$ Hepes in normal saline, $\mathrm{pH}$ 7.4) was injected into the renal artery and samples were collected in the usual fashion. $1 \mathrm{~g} / 100 \mathrm{ml}$ of the bovine c.a. was included in the radioactive injection solution of the second run and $25 \mathrm{mg} / \mathrm{kg}$ i.v. of this enzyme was infused for 5 min before the third run.

\section{RESULTS}

In vitro experiments. Under control conditions, the passage of ${ }^{14} \mathrm{CO}_{2}$ through the kidney perfused without erythrocytes was much more rapid than that of $\mathrm{H}^{14} \mathrm{CO}_{3}^{-}$(see upper panels of Figs. 2 and 3 ). The initial recovery, $\mathrm{R}$, of ${ }^{14} \mathrm{C}$ after injections of ${ }^{14} \mathrm{CO}_{2}$ exceeded that following injections of $\mathrm{H}^{14} \mathrm{CO}_{3}^{-}$by a factor of more than four (Fig. 4). Furthermore, the mean transit times of ${ }^{14} \mathrm{CO}_{2}$ were significantly shorter than those of $\mathrm{H}^{14} \mathrm{CO}_{3}^{-}\left(T_{14 \mathrm{CO}_{2}}\right.$ was only one-third of $\left.T_{\mathrm{H}^{14} \mathrm{CO}_{5}}\right)$. In 9 of 10 control studies, the fractional concentration of ${ }^{14} \mathrm{CO}_{2}$ actually exceeded that of ${ }^{125} \mathrm{I}$-albumin (by an average factor of $5.6 \pm 2.4 \mathrm{SEM}$ ) in the first collection tube that contained radioactivity. This never occurred with $\mathrm{H}^{14} \mathrm{CO}_{3}^{-}$.

After perfusion of the kidney with $200 \mathrm{mg} /$ liter c.a., the outflow patterns of ${ }^{14} \mathrm{CO}_{2}$ became very similar to those of $\mathrm{H}^{14} \mathrm{CO}_{3}^{-}$(lower panels of Fig. 2). This similarity was reflected in terms of both the initial recovery and mean transit times of these indicators (Fig. 4). Changes in $\mathrm{H}^{14} \mathrm{CO}_{3}^{-}$parameters were not significant.

Perfusion with acetazolamide also slowed ${ }^{14} \mathrm{CO}_{2}$ transport through the kidney but did not have as great an effect on initial recovery of ${ }^{14} \mathrm{CO}_{2}$ as c.a. (lower panels of Fig. 3). The initial recoveries of ${ }^{14} \mathrm{CO}_{2}$ fell significantly from control values $(P<0.01)$, but remained significantly greater than those of $\mathrm{H}^{14} \mathrm{CO}_{3}^{-}$af- 


\section{CONTROL}

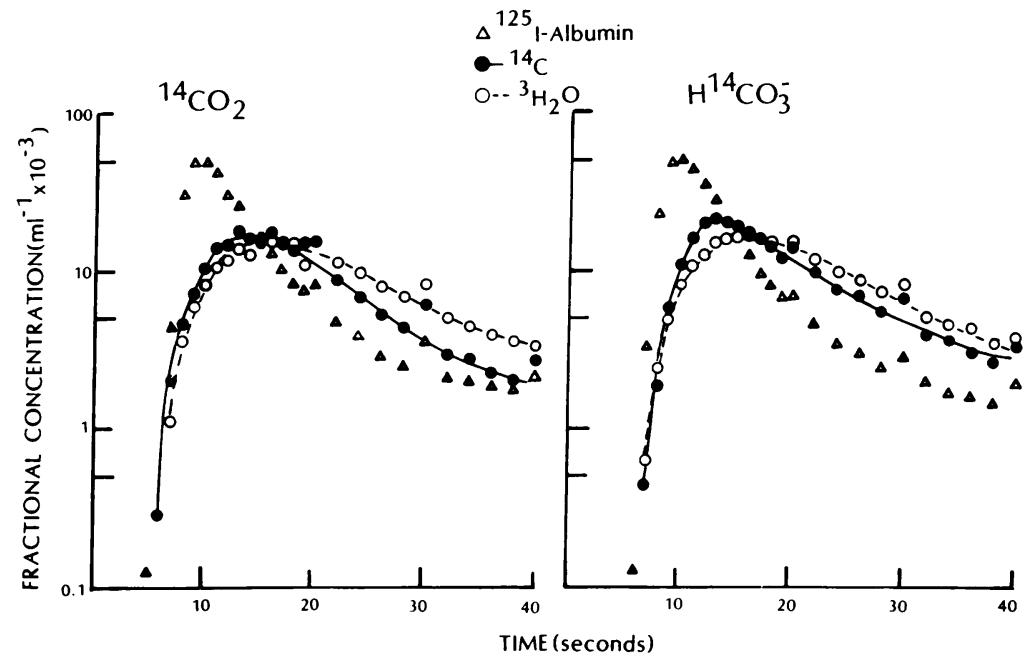

FigUre 5 In vivo control study. Semilogarithmic coordinates are used to facilitate visual comparison of the initial concentrations of the ${ }^{14} \mathrm{C}$ and ${ }^{3} \mathrm{H}$ indicators. Although the outflow patterns of ${ }^{14} \mathrm{CO}_{2}$ and $\mathrm{H}^{14} \mathrm{CO}_{3}^{-}$are quite similar, $R_{11}$ for ${ }^{14} \mathrm{CO}_{2}$ proved to be slightly greater than that of $\mathrm{H}^{14} \mathrm{CO}_{3}^{-}$.

ter infusion of from 20 to $100 \mathrm{mg} /$ liter acetazolamide (Fig. 4, $P<0.01$ ). Despite the fact that $\mathrm{R}_{{ }_{4} \mathrm{CO}_{2}}$ was greater than $R_{\mathrm{H}^{14} \mathrm{CO}}$, $\mathrm{T}$ values for these indicators were not significantly different. This reflects the fact that although some of the ${ }^{14} \mathrm{CO}_{2}$ reaches the venous outflow very rapidly, the remainder is released from the renal tissue quite slowly.

Total recovery of ${ }^{14} \mathrm{C}$ relative to ${ }^{125} \mathrm{I}$-albumin averaged $1.02 \pm 0.10(n=40, \mathrm{SD})$ and was not significantly changed by experimental protocols.

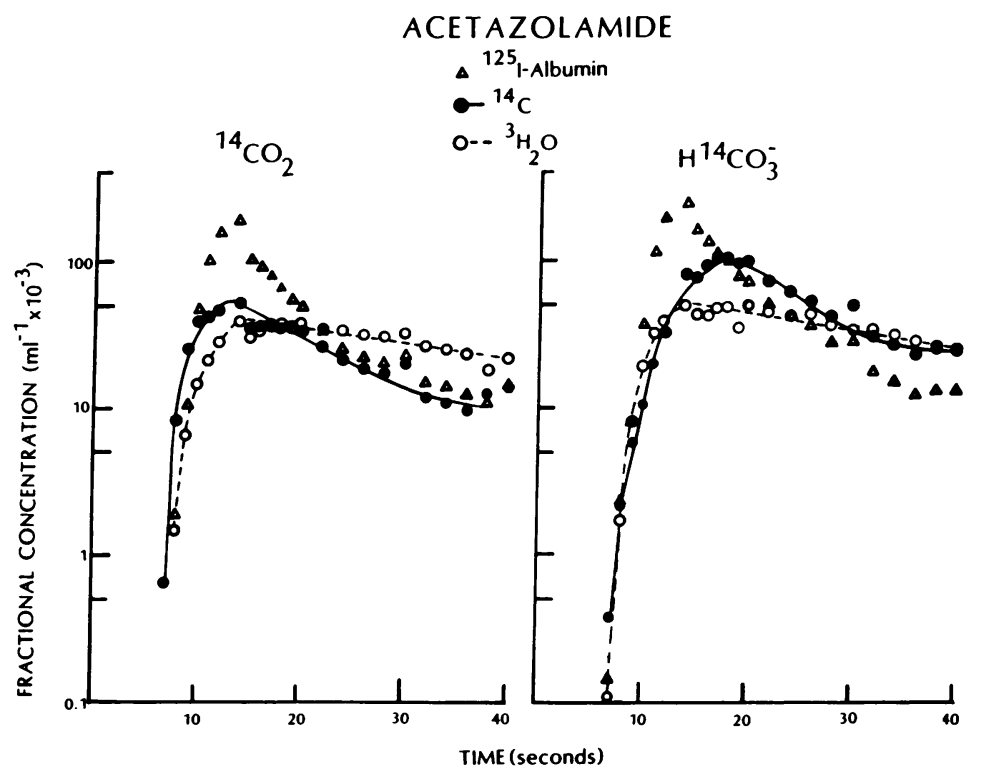

FIGURE 6 In vivo acetazolamide study. Intravenous injection of this inhibitor of c.a. has shifted the ${ }^{14} \mathrm{CO}_{2}$ curve to earlier times than that of $\mathrm{H}^{14} \mathrm{CO}_{3}^{-}$. 


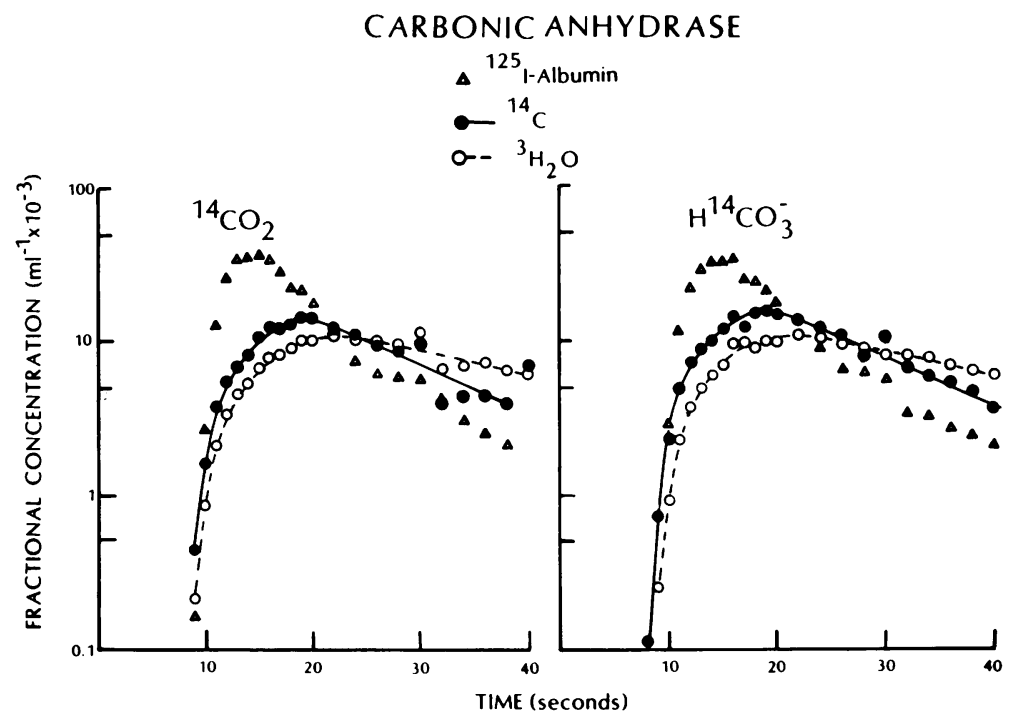

FIGURE 7 In vivo c.a. study. Intravenous injection of this enyzme tended to increase $R$ values of $\mathrm{H}^{14} \mathrm{CO}_{3}^{-}$somewhat more than those of ${ }^{14} \mathrm{CO}_{2}$.

Infusions of acetazolamide had no effect on the mean extravascular $\mathrm{pH}$, which was $7.30 \pm 0.06$ (SEM, $n=5)$ in the control studies and $7.32 \pm 0.03$ in the acetazolamide studies. Arterial $\mathrm{pH}$ averaged $7.42 \pm 0.01$ in the control experiments and $7.41 \pm 0.01$ in the acetazolamide experiments.

In vivo experiments. The following average values were obtained (with the exception of hematocrit, values of individual runs in each experiment were averaged and the average values of all the experiments were then averaged): arterial pressure, $82 / 49$; renal blood flow, $0.52 \pm 0.36 \mathrm{ml} / \mathrm{s}$ (SD); arterial $\mathrm{pH}$, $7.40 \pm 0.08$; arterial $\mathrm{PCO}_{2}, 33 \pm 6$ torr; arterial $\mathrm{PO}_{2}$, $91 \pm 22$ torr; initial hematocrit, $0.32 \pm 0.06$. There was a tendency for hematocrit to decline between runs (by an average of 0.04 ) but no consistent changes were found in the other parameters.

Under in vivo conditions, the outflow patterns of ${ }^{14} \mathrm{CO}_{2}$ and $\mathrm{H}^{14} \mathrm{CO}_{3}^{-}$were much more similar than in the in vitro studies (compare Figs. 2 and 5): the transit of ${ }^{14} \mathrm{CO}_{2}$ through the kidneys of these anesthetized rabbits was only slightly faster than that of $\mathrm{H}^{14} \mathrm{CO}_{3}^{-}$. Although $R_{\mathrm{H}}$ of ${ }^{14} \mathrm{CO}_{2}$ was significantly greater than that of $\mathrm{H}^{14} \mathrm{CO}_{3}^{-}(P<0.01), R_{1}$ values for these radionuclides were not significantly different (Figs. 5 and 8). This observation suggests that equilibration between ${ }^{14} \mathrm{CO}_{2}$ and $\mathrm{H}^{14} \mathrm{CO}_{3}^{-}$is not quite complete by the time they reach the exchange vessels of the kidney.

Equilibration between ${ }^{14} \mathrm{CO}_{2}$ and $\mathrm{H}^{14} \mathrm{CO}_{3}^{-}$was slowed by inhibiting c.a. with acetazolamide. This served to accelerate transit of ${ }^{14} \mathrm{CO}_{2}$ through the renal vascu- lature $\left(R_{1}\right.$ increased $70 \%$ from control studies, $P$ $<0.01$ ), but had no measurable effect on $\mathrm{H}^{14} \mathrm{CO}_{3}^{-}$transit (Figs. 6 and 8). $\left({ }^{3} \mathrm{H}_{2} \mathrm{O}\right.$ was not used in some of these experiments and only $R_{\mathrm{I}}$ was calculated.)

Addition of bovine c.a. to the plasma phase seemed to facilitate the movement of both ${ }^{14} \mathrm{CO}_{2}$ and $\mathrm{H}^{14} \mathrm{CO}_{3}^{-}$(and paradoxically made both $R_{1}$ and $R_{\mathrm{H}}$ of $\mathrm{H}^{14} \mathrm{CO}_{3}^{-}$slightly greater than the corresponding values of ${ }^{14} \mathrm{CO}_{2}, P<0.01$, Figs. 7 and 8 ).

These observations concerning the effects of c.a. on $R_{\mathrm{H}}$ were corroborated by the experiments in which a single injection of an equilibrated mixture of $95 \%$ $\mathrm{H}^{14} \mathrm{CO}_{3}^{-}$and $5 \%{ }^{14} \mathrm{CO}_{2}$ was injected into the renal artery (Fig. 9). Incorporation of c.a. in the injection solution increased $R_{\mathrm{H}}$ and when the enzyme was infused intravenously, $R_{\mathrm{H}}$ rose further $(P<0.01)$. That these changes were not simply due to a decline in hematocrit was determined in two similar studies in which no c.a. was used: values of $R_{1}$ and $R_{\mathrm{H}}$ actually declined slightly as hematocrits fell by $10 \%$. Nor did the order of the control studies with ${ }^{14} \mathrm{CO}_{2}$ and $\mathrm{H}^{14} \mathrm{CO}_{3}^{-}$injections (randomized in 12 experiments) affect the outflow patterns.

The concentration of c.a. in the plasma was less than that contained in a 1:50,000 dilution of hemolyzed erythrocytes in four experiments and less than a 1:20,000 dilution in one experiment.

\section{DISCUSSION}

Under control conditions, ${ }^{14} \mathrm{C}$ label appears in the renal venous outflow at an earlier time following arterial 

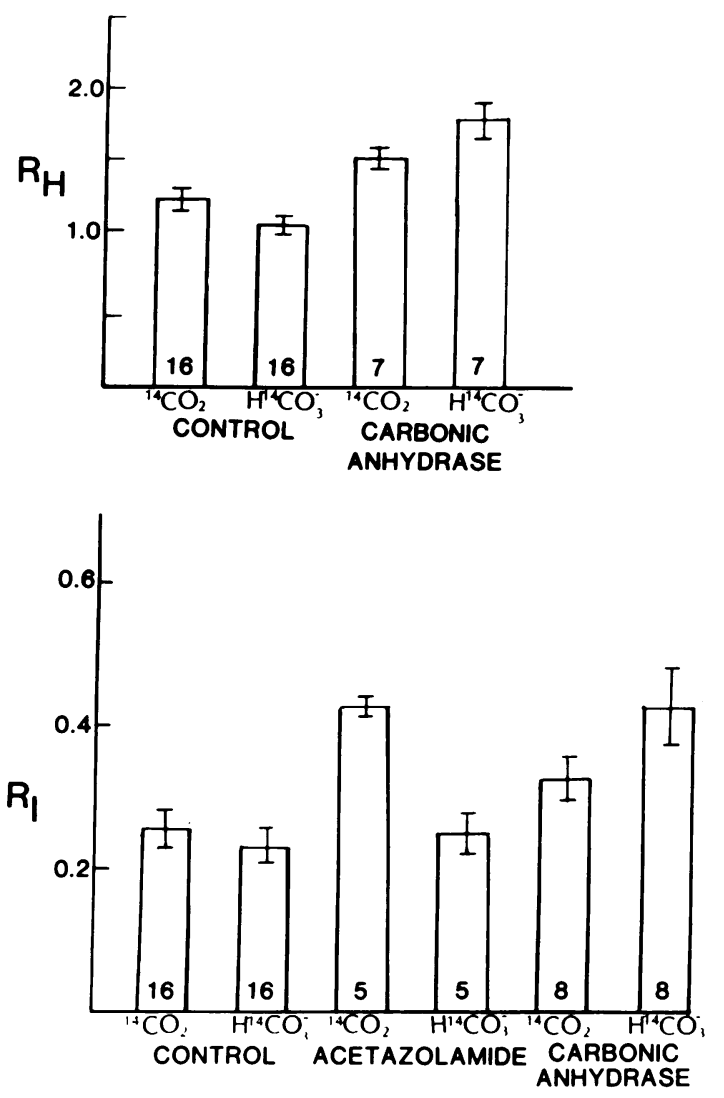

Figure 8 Summary of in vivo studies. Mean values of $R_{1}$ and $R_{11}$ are indicated with standard errors. Control $R_{11}$ values of ${ }^{14} \mathrm{CO}_{2}$ were slightly but significantly greater than those of $\mathrm{H}^{14} \mathrm{CO}_{3}^{-}(P<0.01)$. Acetazolamide significantly increased $R_{1}$ of ${ }^{14} \mathrm{CO}_{2}$ but had no effect on $R_{1}$ of $\mathrm{H}^{14} \mathrm{CO}_{3}^{-}$. (Values of $R_{11}$ were not obtained in some of the acetazolamide studies and a mean value is not shown). c.a. increased $R_{1}$ and $R_{11}$ of both ${ }^{14} \mathrm{CO}_{2}$ and $\mathrm{H}^{14} \mathrm{CO}_{3}^{-}$. In vivo $R_{1}$ data cannot be directly compared with in vitro data because of differences in buffering capacity of blood and perfusate.

injections of ${ }^{14} \mathrm{CO}_{2}$ than after similar injections of $\mathrm{H}^{14} \mathrm{CO}_{3}^{-}$. Indeed, at the earliest times, fractional concentrations of ${ }^{14} \mathrm{CO}_{2}$ generally exceeded those of the vascular indicator, ${ }^{125} \mathrm{I}$-albumin. It can be predicted that some of the injected ${ }^{14} \mathrm{CO}_{2}$ will be converted to $\mathrm{H}^{14} \mathrm{CO}_{3}^{-}$at the uncatalyzed rate $\left(\mathrm{t}_{1 / 2}=5.5 \mathrm{~s}\right)(3)$ before reaching the renal microcirculation, but much of it apparently remains as ${ }^{14} \mathrm{CO}_{2}$. These observations suggest that ${ }^{14} \mathrm{CO}_{2}$, like oxygen, tritium gas, 85-krypton, heat, and alcohols, diffuses directly from arterial sources to venous sinks within the kidney (20-24). Shunting results in the relatively early appearance of these indicators in the renal venous blood and skewing of the indicator dilution curves towards earlier times. This change is most easily evaluated by dividing the

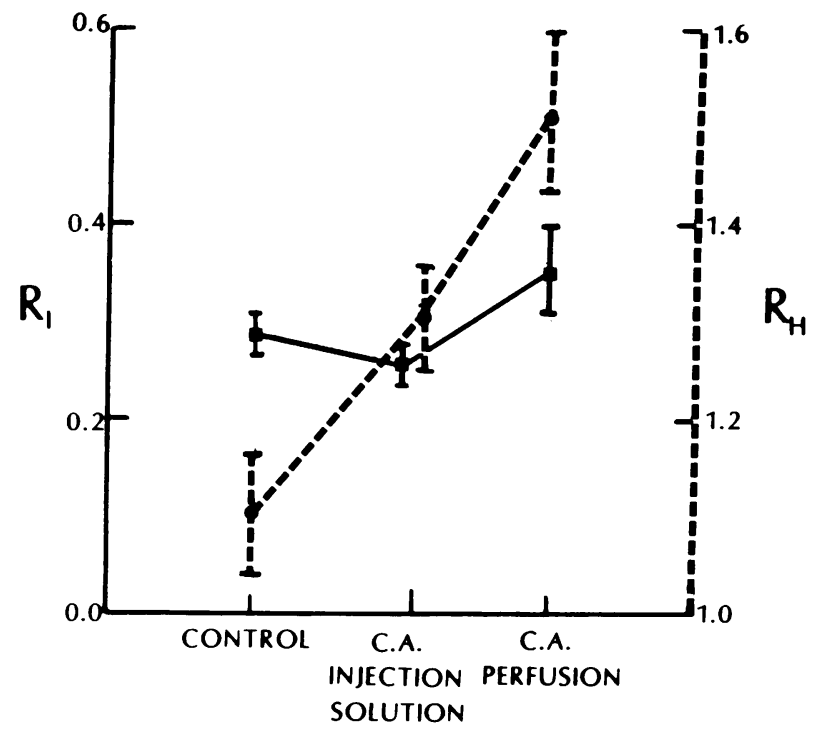

Figure 9 Single injection studies (in vivo). The injection solution contained an equilibrated mixture of $5 \%{ }^{14} \mathrm{CO}_{2}$ and $95 \% \mathrm{H}^{14} \mathrm{CO}_{3}^{-}$. Incorporation of c.a. in the injection solution increased $R_{11}$ of this mixture and infusion of c.a. further increased $R_{11}$. The changes in $R_{1}$ were not significant.

initial concentrations of the diffusible indicator dilution curve by vascular indicator concentrations to yield $R$, a procedure analogous to those used by Crone and others $(25,26)$ for measuring capillary permeability in a variety of organs.

In theory, the mean transit time of each indicator should be determined by its virtual volume of distribution within the kidney rather than the manner in which it traverses the organ (27). The observation that the mean transit time of ${ }^{14} \mathrm{CO}_{2}$ was shorter than that of $\mathrm{H}^{14} \mathrm{CO}_{3}^{-}$probably reflects the fact that the collection periods were limited to a 40-s interval and the late efflux of ${ }^{14} \mathrm{CO}_{2}$ from more remote compartments of the kidney was not given sufficient weight. The fact that recovery of ${ }^{14} \mathrm{CO}_{2}$ seemed complete in comparison to ${ }^{125} \mathrm{I}$-albumin does not ensure that the monoexponential outflow pattern assumed in these studies is correct or that the calculated mean transit times are appropriate. The late emergence of a small amount of indicator could significantly lengthen the mean transit time of ${ }^{14} \mathrm{CO}_{2}$.

In contrast to ${ }^{14} \mathrm{CO}_{2}$, diffusional shunting of $\mathrm{H}^{14} \mathrm{CO}_{3}^{-}$from arterial to venous vessels seems relatively limited. The renal vessels, like those of the lung and leg, appear to be much less permeable to this ion than to ${ }^{14} \mathrm{CO}_{2}$. Alternatively, structures that separate arterial and venous vessels may be impermeable to these ions. $\mathrm{H}^{14} \mathrm{CO}_{3}^{-}$is presumably delivered with ${ }^{125} \mathrm{I}$-albumin to the nephrons by the peritubular capillaries. 
Unlike ${ }^{125} \mathrm{I}$-albumin, it then diffuses into the extravascular compartment and consequently arrives in the renal venous blood at a later time than either ${ }^{125} \mathrm{I}-\mathrm{al}-$ bumin or ${ }^{14} \mathrm{CO}_{2}$.

The site at which ${ }^{14} \mathrm{CO}_{2}$ or other lipophilic solutes diffuse from arterial to venous vessels cannot be determined from outflow studies. Since $90 \%$ of the renal blood flow is cortical (28), it is likely that much of the shunting found in outflow experiments occurs in the renal cortex. A close proximity is found between arteries and veins in the interlobar, arcuate, and interlobular vessels and some exchange could occur between these adjacent flows. Even more shunting would be expected between adjacent capillaries. The interlobular arteries extend into the cortex in a radial fashion, giving rise to successive generations of afferent arterioles, which in turn supply the glomeruli. The efferent arterioles drain the glomeruli and form a complex, but continuous network of capillaries that surrounds the tubules. In more than half of these capillaries, flow is in the opposite direction to that of tubular fluid in the neighboring nephron (29). It is quite likely that diffusion of lipophilic solutes injected into the renal artery could diffuse between adjacent capillary segments in a manner that would hasten their emergence from the kidney.

Diffusion of $\mathrm{CO}_{2}$ between adjacent vessels may also contribute to high $\mathrm{PCO}_{2}$ and $\mathrm{HCO}_{3}^{-}$concentrations found in the efferent arteriolar blood on the kidney surface (14). $\mathrm{CO}_{2}$ generated within the superficial cortex might diffuse from venous to arterial vessels in a countercurrent fashion that would tend to keep $\mathrm{PCO}_{2}$ elevated in this region. Equilibration with $\mathrm{HCO}_{3}^{-}$ would be approached in the blood, thereby elevating regional blood $\mathrm{HCO}_{3}^{-}$concentrations. Such a diffusional shunt of $\mathrm{CO}_{2}$ produced within the cortex might occur between interlobular vessels or adjacent capillary segments. Since less energy need be expended to maintain a $\mathrm{PCO}_{2}$ gradient over a greater distance (e.g., between the superficial and deep cortex) than over a shorter distance (e.g., between different portions of a nephron), the hypothesis of macroscopic countercurrent mechanism is appealing. Shunting of heat between arterial and venous vessels has been reported and is thought to be responsible for slow clearance of this extremely "diffusible" indicator from the superficial cortex $(23,24)$. Similarly, it has been suggested that diffusion of $\left[{ }^{125} \mathrm{I}\right]$ iodoantipyrine between deeper cortical vessels may be responsible for the observation that blood flow estimated in the more superficial regions is less than that obtained with microspheres (30). The observation that $\mathrm{PCO}_{2}$ is not elevated in tubular fluid of the medulla is also consistent with countercurrent diffusion in the cortex (31).
The distinctly different outflow patterns of ${ }^{14} \mathrm{CO}_{2}$ and $\mathrm{H}^{14} \mathrm{CO}_{3}^{-}$indicate that there is insufficient c.a. on the luminal surface of the renal arteries or exchange vessels initially encountered by the perfusion fluid to ensure equilibration between these radionuclides. This hypothesis is confirmed by the observation that the outflow patterns of ${ }^{14} \mathrm{CO}_{2}$ and $\mathrm{H}^{14} \mathrm{CO}_{3}^{-}$become the same when c.a. is added to the perfusate. Histochemical studies have shown that there is abundant c.a. associated with the cytoplasm and membranes of many of the tubular epithelial cells (32-36). Relatively little attention has been given to renal vascular c.a. However, the enzyme is not detectable in glomerular capillaries of mammals, an observation that is consistent with our observation that there is a deficiency of c.a. activity on the luminal surfaces of at least some vessels of the rabbit kidney. The histochemical studies have detected activity in the vasa rectae of man but not in those of rats.

Following administration of acetazolamide, the initial appearance of ${ }^{14} \mathrm{CO}_{2}$ remained earlier than that of $\mathrm{H}^{14} \mathrm{CO}_{3}^{-}$but ${ }^{14} \mathrm{CO}_{2}$ transit through the kidney was clearly slower than under control conditions. This observation was unexpected and suggested that a more complete model of $\mathrm{CO}_{2}$ exchange was needed. There are three ways in which the acetazolamide effect upon ${ }^{14} \mathrm{CO}_{2}$ could be explained.

(a) If acetazolamide increases the average $\mathrm{pH}$ of the extravascular compartments of the kidney, a prolongation and lowering of the outflow pattern of ${ }^{14} \mathrm{CO}_{2}$ would be expected. This effect of increasing the relative $\mathrm{pH}$ of the extravascular space has been observed in indicator dilution studies of the lungs and myocardium $(16,18,19)$. Since no significant changes in mean extravascular $\mathrm{pH}$ were detected in this preparation with transient studies using the $\mathrm{pH}$ indicator, $\left[{ }^{14} \mathrm{C}\right] \mathrm{DMO}$, this hypothesis seems unlikely.

(b) If c.a. is located specifically on the luminal surface of the more venous vessels of the kidney, conversion of ${ }^{14} \mathrm{CO}_{2}$ diffusing into these vessels to $\mathrm{H}^{14} \mathrm{CO}_{3}^{-}$would lower local concentrations of ${ }^{14} \mathrm{CO}_{2}$ and encourage diffusional shunting from arterial to venous vessels. Inhibition of c.a. at this site would make this process less efficient. As indicated above, the enzyme has been detected on the postglomerular capillaries of some species (primates not rats) (32-36). However, there is also abundant enzyme activity associated with the tubular epithelium and it is likely that much of the ${ }^{14} \mathrm{CO}_{2}$ that escapes from the renal vessels is converted to $\mathrm{H}^{14} \mathrm{CO}_{3}^{-}$in the extravascular compartments of the kidney. There is consequently little reason to believe that such a mechanism would effectively direct ${ }^{14} \mathrm{CO}_{2}$ into the renal venous outflow.

(c) A more plausible explanation for the effect of 
acetazolamide is based upon the possible role of tissue c.a. in accelerating the conversion of $\mathrm{H}^{14} \mathrm{CO}_{3}^{-}$to ${ }^{14} \mathrm{CO}_{2}$ at the interface between aqueous and lipid phases at the cell surfaces. This hypothesis is based upon three assumptions:

(i) The ${ }^{14} \mathrm{C}$ label is carried across the cell membranes most rapidly when it is in the form of ${ }^{14} \mathrm{CO}_{2}$. Much of the ${ }^{14} \mathrm{CO}_{2}$ injected in the control experiments apparently remains in this form because there is no c.a. in the plasma or associated with the arterial and initial exchange vessels of the kidney. $\left(\right.$ ii) ${ }^{14} \mathrm{C}$ moves more slowly across cell membranes when it is in the form of $\mathrm{H}^{14} \mathrm{CO}_{3}^{-}$and ${ }^{14} \mathrm{CO}_{2}$ at physiological $\mathrm{pH}$ in the presence of c.a. This is presumably the situation in the renal vasculature when c.a. is added to the perfusate. Such infusions of this enzyme inhibit early diffusion of the ${ }^{14} \mathrm{C}$ label out of the initial vessels by reducing the concentration of ${ }^{14} \mathrm{CO}_{2}$ at the surface of the endothelial cells facing the plasma. A similar situation presumably prevails near many of the lipid membranes in the extravascular space of the kidney since there are large amounts of enzymes at most of these sites. $(i i i){ }^{14} \mathrm{C}$ label is carried across the cell membranes least rapidly when it is mostly in the form of $\mathrm{H}^{14} \mathrm{CO}_{3}^{-}$in the absence of c.a. This is responsible for the delay in emergence of $\mathrm{H}^{14} \mathrm{CO}_{3}^{-}$in control studies because it is not rapidly converted to ${ }^{14} \mathrm{CO}_{2}$ by c.a. and is consequently retained in the vasculature compartment and does not diffuse directly into the venous vessels.

These assumptions have been shown to be valid in the pulmonary and leg circulations (1-5) and similar data have been reported by Gutknecht et al. (37) for artificial lipid bilayers. Indeed, it was possible to show that $\mathrm{H}^{14} \mathrm{CO}_{3}^{-}$exchanges across the alveolar capillary barrier at least 600 times more slowly than ${ }^{14} \mathrm{CO}_{2}(5)$.

The effect of acetazolamide can be explained with the aid of Fig. 10. During both control and acetazolamide infusions, ${ }^{14} \mathrm{CO}_{2}$ readily crosses the initial capillary walls (B). Under control conditions, much of the ${ }^{14} \mathrm{CO}_{2}$ that has left the circulation $(\mathrm{C})$ is hydrated at the uncatalyzed rate $\left(t_{1 / 2}=5.5 \mathrm{~s}\right)$. Nearly complete equilibration between ${ }^{14} \mathrm{CO}_{2}$ and $\mathrm{H}^{14} \mathrm{CO}_{3}^{-}$occurs at the cell membranes and in the cytoplasm of many of the tubular cells that contain c.a. Although much of the ${ }^{14} \mathrm{C}$ label is in the form of $\mathrm{H}^{14} \mathrm{CO}_{3}^{-}$at these sites, the presence of enzyme ensures that conversion of $\mathrm{H}^{14} \mathrm{CO}_{3}^{-}$to ${ }^{14} \mathrm{CO}_{2}$ is rapid and movement of the ${ }^{14} \mathrm{C}$ label across cellular membranes to the renal outflow is prompt. The movement of the ${ }^{14} \mathrm{C}$ label in the aqueous compartments may be accelerated by the parallel movement of $\mathrm{H}^{14} \mathrm{CO}_{3}^{-}$and ${ }^{14} \mathrm{CO}_{2}$ as suggested by Enns (38). Furthermore it is also possible that enzyme located on cell membranes could transport $\mathrm{H}^{14} \mathrm{CO}_{3}^{-}$

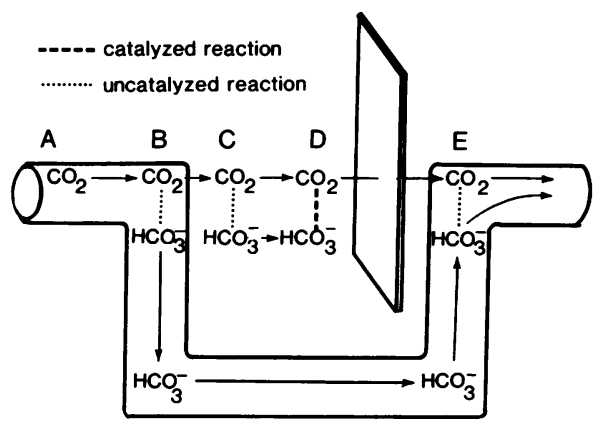

Figure 10 Schematic diagram of ${ }^{14} \mathrm{CO}_{2}$ and $\mathrm{H}^{14} \mathrm{CO}_{3}^{-}$transit through the kidney in control studies after an injection of ${ }^{14} \mathrm{CO}_{2}$ (isotope numbers deleted for clarity). The bent cylinder represents the exchange vessels of the renal cortex, whereas the plane indicates a lipid cell membrane that is assumed to be associated with c.a. The movement of ${ }^{14} \mathrm{CO}_{2}$ is by direct diffusion from the arterial to venous portions of the microcirculation ( $B$ to $E$ ). Some ${ }^{14} \mathrm{CO}_{2}$ is converted to $\mathrm{H}^{14} \mathrm{CO}_{3}^{-}$within the vessels at the uncatalyzed rate. The $\mathrm{H}^{14} \mathrm{CO}_{3}^{-}$is then carried by blood flow through the vessels from $\mathrm{B}$ to $\mathrm{E}$, a process that requires more time than direct ${ }^{14} \mathrm{CO}_{2}$ diff usion between these points. Much of the ${ }^{14} \mathrm{CO}_{2}$ that escapes from the vessel is converted to $\mathrm{H}^{14} \mathrm{CO}_{3}^{-}$at the uncatalyzed rate in the interstitium (C) or at the catalyzed rate on the cell membrane surface (D).

across the lipid barrier. When renal c.a. is inhibited by acetazolamide, whatever ${ }^{14} \mathrm{CO}_{2}$ that has been converted to $\mathrm{H}^{14} \mathrm{CO}_{3}^{-}$at the uncatalyzed rate $(\mathrm{C})$ will no longer be rapidly reconverted to ${ }^{14} \mathrm{CO}_{2}$ at the cellular borders (D). That this is the correct explanation for the acetazolamide data is suggested by the observation that although initial outflow concentrations of ${ }^{14} \mathrm{CO}_{2}$ are higher than those of $\mathrm{H}^{14} \mathrm{CO}_{3}^{-}$after infusions of acetazolamide, subsequent washout of ${ }^{14} \mathrm{C}$ is relatively slower. Presumably with the passage of time, more of the ${ }^{14} \mathrm{CO}_{2}$ that remains outside of the vessels is converted to $\mathrm{H}^{14} \mathrm{CO}_{3}^{-}$at the uncatalyzed rate.

Although a disequilibrium of ${ }^{14} \mathrm{CO}_{2}$ and $\mathrm{H}^{14} \mathrm{CO}_{3}^{-}$ occurs in some of the renal vessels in these perfused kidneys, it cannot be concluded that a similar disequilibrium would also be observed in vivo. There is considerable enzyme within erythrocytes that might promote equilibration between ${ }^{14} \mathrm{CO}_{2}$ and $\mathrm{H}^{14} \mathrm{CO}_{3}^{-}$in the vascular compartment. Indeed, the studies with the in vivo kidney preparation indicate that in the presence of erythrocytes, the outflow patterns of these radionuclides are nearly the same. Infusions of acetazolamide inhibited c.a. in the erythrocytes as well as the kidney and the outflow patterns of ${ }^{14} \mathrm{CO}_{2}$ and $\mathrm{H}^{14} \mathrm{CO}_{3}^{-}$again become dissimilar. However, the fact that equilibration is almost reached by the time the indicators are delivered from the renal artery to the capillaries does not prove that equilibrium is sustained within the capillaries. If the movement of ${ }^{14} \mathrm{CO}_{2}$ from 
the capillaries is sufficiently rapid and the dehydration of $\mathrm{H}^{14} \mathrm{CO}_{3}^{-}$is sufficiently slow, a disequilibrium between these radionuclides will be generated in the capillaries, which could limit tissue exchange. That this might indeed be the case is suggested by the experiments with c.a., which seemed to accelerate the movement of both ${ }^{14} \mathrm{CO}_{2}$ and $\mathrm{H}^{14} \mathrm{CO}_{3}^{-}$through the kidney. The observation that the effect upon $\mathrm{H}^{14} \mathrm{CO}_{3}^{-}$transport was slightly greater than that upon ${ }^{14} \mathrm{CO}_{2}$ is difficult to explain and may have been due to an artifact (such as some ${ }^{14} \mathrm{CO}_{2}$ loss from the acidic injection syringes). In order to confirm that c.a. does accelerate ${ }^{14} \mathrm{C}$ exchange, single injections containing $5 \%{ }^{14} \mathrm{CO}_{2}$ and $95 \%$ $\mathrm{H}^{14} \mathrm{CO}_{3}^{-}$were given into the renal artery. Addition of c.a. to the injection solution did increase $\boldsymbol{R}_{\mathrm{H}}$ and this effect was further increased by infusions of the enzyme. The greater effect of the infusions could reflect diffusion of the enzyme to some extravascular sites that are relatively deficient in c.a. activity. It has been proposed by Roughton (39) and Forster and Crandall (40) that because the erythrocyte enzyme is strictly intra- cellular, delays in equilibration are inevitable. The absence of carbonic anhydrase bound to the surface of endothelial cells might be responsible for some degree of disequilibrium within the renal vessels in vivo.

It is by no means obvious why the renal endothelium, unlike that of the leg or lung, is deficient in c.a. activity. In contrast to the pulmonary epithelium, which seems devoid of c.a. $(4,10)$, and the muscle cells, which contain a very inactive form of the enzyme (41-43), there is abundant c.a. activity associated with both the cytoplasm and membranes of many renal tubular cells (32-36). There may, consequently, be little need for additional c.a. in the kidney vasculature. Because the renal tubular cells secrete hydrogen ions into the tubular lumen, the cells themselves are alkaline relative to the plasma and presumably the interstitium as well $(44,45)$. Although there may well be enough c.a. within the cells to promote full equilibration between $\mathrm{HCO}_{3}^{-}$and $\mathrm{CO}_{2}$ intracellularly, the transport of $\mathrm{HCO}_{3}^{-}$into the more acid environment of the interstitium might result in the maintenance of a small

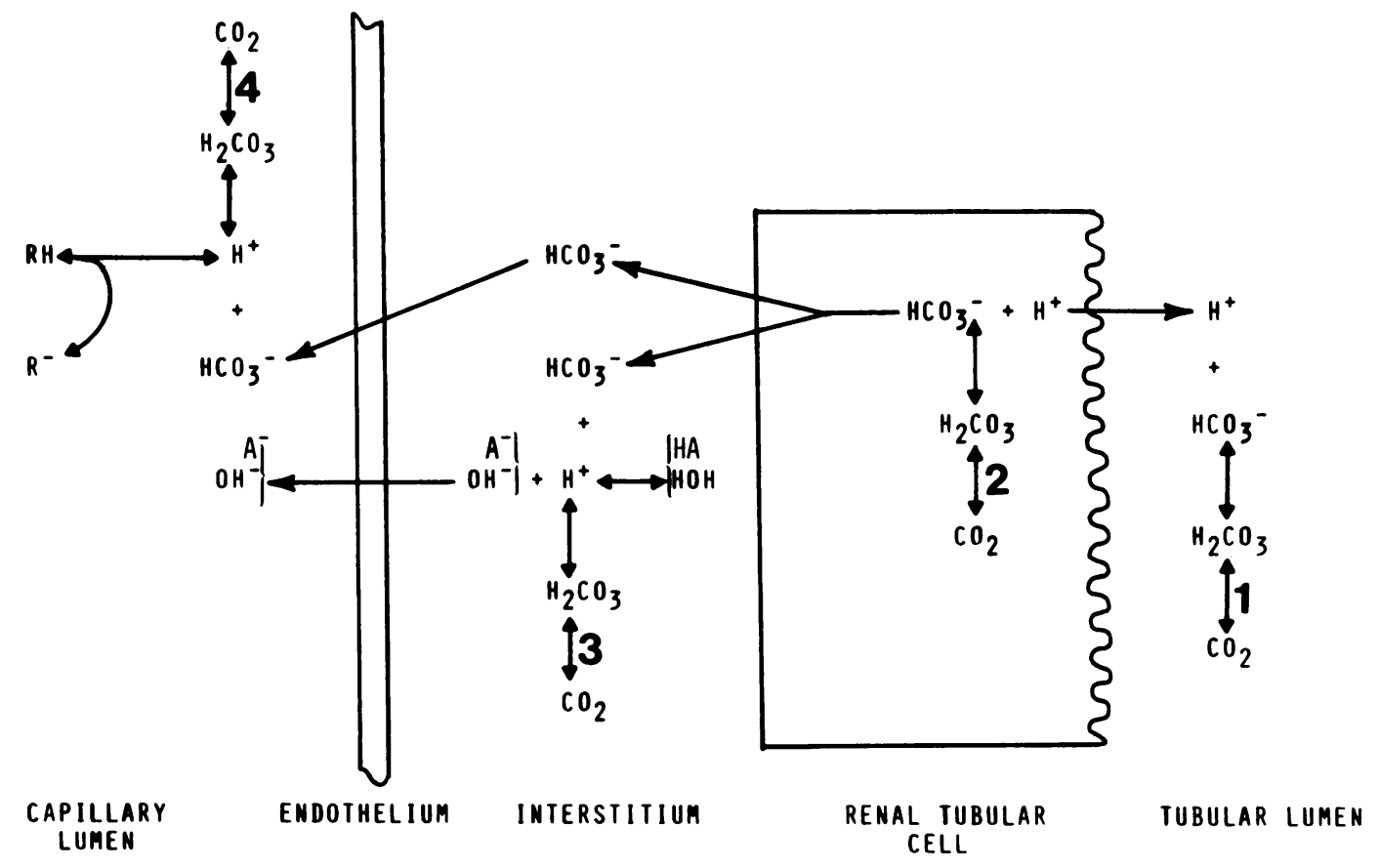

FIGURE $11 \mathrm{CO}_{2}-\mathrm{HCO}_{3}^{-}$equilibration in renal compartments. Site 1 indicates the reaction in the tubular lumen: c.a. bound to the brush border of proximal tubular cells may catalyze this reaction. Site 2 represents the same reaction in the tubular cellular compartment: c.a. is present in many of the tubular cells. Secretion of $\mathrm{H}^{+}$is responsible for the fact that cellular $\mathrm{pH}$ is relatively alkaline compared to plasma. The interstitial reaction is shown at site 3 . It is not clear whether there is c.a. on the surface of the renal tubular cells facing the interstitium or whether any enzyme at this site would be accessible to all the fluid in the interstitium. Since there is a deficiency of carbonic anhydrase on the blood side of the endothelial cells, there may be none facing the interstitium. A disequilibrium in this compartment would favor return of $\mathrm{HCO}_{3}^{-}$rather than $\mathrm{OH}^{-}$or buffer anions $\left(\mathrm{A}^{-}\right)$to the vascular lumen. Equilibration may be incomplete in the plasma (site 4 ) if erythrocyte c.a. is sufficiently inaccessible. 
disequilibrium in this compartment if c.a. is deficient in the interstitium (see Fig. 11). Since the average renal cellular $\mathrm{pH}$ is only $0.1 \mathrm{U}$ above that of the plasma (44, 45), it seems unlikely that a disequilibrium greater than this would be sustained in the interstitium. As indicated in Fig. 11, the presence of c.a. in the interstitium would act to decrease $\mathrm{HCO}_{3}^{-}$concentrations and increase buffer and hydroxyl anions. Although not shown in the figure, hydrogen ion might also be secured from the plasma and/or from cationic acids (such as $\mathrm{NH}_{4}^{+}$). Whether the presence of c.a. in the interstitium would tend to make the return of base equivalents to the blood more or less efficient would depend upon the availability of these alternative ions and the relative permeability of the endothelium to $\mathrm{HCO}_{3}^{-}$and the alternative ions. Until information of this nature is available, the significance of a c.a. deficiency on the renal endothelial wall and its role in the formation of $\mathrm{CO}_{2}$ gradients within the kidney will remain uncertain.

\section{ACKNOWLEDGMENTS}

We would like to acknowledge the fine technical assistance of Ellen Reid and Phillip Silverman as well as secretarial help provided by John Grennan. This research was supported by National Institutes of Health grant HL28255.

\section{REFERENCES}

1. Effros, R. M., R. S. Y. Chang, and P. Silverman. 1978. Acceleration of plasma bicarbonate conversion to carbon dioxide by pulmonary carbonic anhydrase. Science (Wash. DC).199: 426-429.

2. Effros, R. M., and M. L. Weissman. 1979. Carbonic anhydrase activity of cat hindleg. J. Appl. Physiol.: Respirat. Environ. Exercise Physiol. 47: 1090-1098.

3. Effros, R. M., L. Shapiro, and P. Silverman. 1980. Carbonic anhydrase activity of rabbit lungs. J. Appl. Physiol.: Respirat. Environ. Exercise Physiol. 49: 589-600.

4. Effros, R. M., G. Mason, and P. Silverman. 1981. Asymmetric distribution of carbonic anhydrase in the alveolar-capillary barrier. J. Appl. Physiol.: Respirat. Environ. Exercise Physiol. 51: 190-193.

5. Effros, R. M., G. Mason, and P. Silverman. 1981. Role of perfusion and diffusion in ${ }^{14} \mathrm{CO}_{2}$ exchange in the rabbit lung. J. Appl. Physiol.: Respirat. Environ. Exercise Physiol. 51: 1136-1144.

6. Klocke, R. A. 1978. Catalysis of $\mathrm{CO}_{2}$ reactions by lung carbonic anhydrase. J. Appl. Physiol.: Respirat. Environ. Exercise Physiol. 44: 882-888.

7. Crandall, E. D., and J. E. O'Brasky. 1978. Direct evidence for participation of rat lung carbonic anhydrase in $\mathrm{CO}_{2}$ reaction. J. Clin. Invest. 62: 618-622.

8. Klocke, R. A. 1980. Equilibrium of $\mathrm{CO}_{2}$ reactions in the pulmonary capillary. J. Appl. Physiol.: Respirat. Environ. Exercise Physiol. 48: 972-976.

9. Fain, W., and S. Rosen. 1973. Carbonic anhydrase activity in amphibian and reptilian lung: a histochemical and biochemical analysis. Histochem. J. 5: 519-528.

10. Lonnerholm, G. 1980. Carbonic anhydrase in the lung. Acta Physiol. Scand. 108: 197-199.
11. Lonnerholm, G. 1980. Carbonic anhydrase in rat liver and rabbit skeletal muscle; further evidence for the specificity of the histochemical cobalt-phosphate method of Hannson. J. Histochem. Cytochem. 28: 427-433.

12. Ryan, U. S., P. L. Whitney, and J. W. Ryan. 1982. Localization of carbonic anhydrase on pulmonary artery endothelial cells in culture. J. Appl. Physiol.: Respirat. Environ. Exercise Physiol. 53: 914-919.

13. Whitney, P. L., and T. V. Briggle. 1982. Membraneassociated carbonic anhydrase purified from bovine lung. J. Biol. Chem. 257: 12056-12059.

14. DuBose, T. D., Jr., L. R. Pucacco, M. S. Lucci, and N. W. Carter. 1981. Micropuncture determination of $\mathrm{pH}, \mathrm{PCO}_{2}$ and total $\mathrm{CO}_{2}$ concentration in accessible structures of the rat cortex. J. Clin. Invest. 64: 476-482.

15. Hodgen, G. D., and R. J. Falk. 1971. A radiotracer assay for carbonic anhydrase. Int. J. Appl. Radiat. Isot. 22: $492-495$.

16. Effros, R. M., B. Haider, P. O. Ettinger, S. S. Ahmed, H. A. Oldewurtel, K. Marold, and T. J. Regan. 1975. In vivo myocardial cell $\mathrm{pH}$ in the dog. J. Clin. Invest. 55: $1100-1110$

17. Waddell, W. J., and T. C. Butter. 1959. Calculation of intracellular $\mathrm{pH}$ from the distribution of 5,5-dimethyl2,4-oxazolidine dione (DMO). J. Clin. Invest. 38: 720727.

18. Effros, R. M., and F. P. Chinard. 1969. The in vivo pH of the extravascular space of the lung. J. Clin. Invest. 48: 1983-1996.

19. Effros, R. M., N. Corbeil, and F. P. Chinard. 1972. Arterial $\mathrm{pH}$ and distribution of barbiturates between pulmonary tissue and blood. J. Appl. Physiol. 33: 656-664.

20. Levy, M. N., and G. Sauceda. 1959. Diff usion of oxygen from arterial to venous segments of renal capillaries. Am. J. Physiol. 196: 1336-1339.

21. Perl, W., and F. P. Chinard. 1968. A convection-diffusion model of indicator transport through an organ. Circ. Res. 22: 273-298.

22. Chinard, F. P., C. N. Thaw, A. C. Delea, and W. Perl. 1969. Intrarenal volumes of distribution and relative diffusion coefficients of monohydric alcohols. Circ. Res. 25: 343-357.

23. Aukland, K. 1967. Renal medullary heat clearance in the dog. Circ. Res. 20: 194-203.

24. Roed, A., and K. Aukland. 1969. Countercurrent exchange of heat in the dog kidney. Cir. Res. 20: 194-203.

25. Crone, C. 1963. The permeability of capillaries in various organs as determined by use of the "indicator diffusion" method. Acta Physiol. Scand. 58: 292-305.

26. Crone, C., and N. A. Lassen, editors. 1970. Capillary permeability. Academic Press, Inc., New York.

27. Meier, P., and K. L. Zierler. 1954. On the theory of the indicator-dilution method for measurement of blood flow and volume. J. Appl. Physiol. 6: 731-744.

28. Aukland, K. 1976. Renal blood flow. In International Review of Physiology Kidney and Urinary Tract Physiology II. K. Thurau, editor. University Park Press, Baltimore, MD. II: 23-79.

29. Kriz, W., J. M. Barrett, and S. Peter. 1976. The renal vasculature: anatomical-functional aspects. In International Review of Physiology Kidney and Urinary Tract Physiology II. K. Thurau, editor. University Park Press, Baltimore, MD. II: 1-21.

30. Clausen, G., A. Hope, A. Kirkeb, I. Tysselbotn, and K. Aukland. 1979. Distribution of blood flow in the dog kidney. I. Saturation rates for inert diffusible tracers, 
${ }^{125}$ I-iodoantipyrine and tritiated water, versus uptake of microspheres under control conditions. Acta Physiol. Scand. 107: 69-81.

31. DuBose, T. D. 1981. Urine to blood $\mathrm{PCO}_{2}$ gradient (UB $\left.\mathrm{PCO}_{2}\right)$ is an index of hydrogen in secretion by collecting duct. Clin. Res. 29: 460a. (Abstr.)

32. Lonnerholm, G. 1971. Histochemical demonstration of carbonic anhydrase activity in the rat kidney. Acta Physiol. Scand. 81: 433-438.

33. Rosen, S. 1972. Localization of carbonic anhydrase activity in the vertebrate nephron. Histochem. J. 4: $35-46$.

34. Spicer, S. S., P. J. Sloward, and R. E. Tashian. 1979. The immunohistolocalization of carbonic anhydrase in rodent tissues. J. Histochem. Cytochem. 27: 820-831.

35. Lonnerholm, G. 1973. Histochemical demonstration of carbonic anhydrase in the human kidney. Acta Physiol. Scand. 88: 455-468.

36. Lonnerholm, G., and Y. Ridderstrale. 1980. Intracellular distribution of carbonic anhydrase in the rat kidney. Kidney Int. 17: 162-174.

37. Gutknecht, J., M. A. Bisson, and F. D. Tosteson. 1977. Diffusion of carbon dioxide through lipid bilayer membranes: effects of carbonic anhydrase, bicarbonate and unstirred layers. J. Gen. Physiol. 69: 779-794.

38. Enns, T. 1967. Facilitation by carbonic anhydrase of carbon dioxide transport. Science (Wash. DC) 155 44-47.

39. Roughton, F. J. W. 1935. Recent work on carbon dioxide transport by the blood. Physiol. Rev. 15: 241-296.

40. Forster, R. E., and E. D. Crandall. 1975. Time course of exchange between red cells and extracellular fluid during $\mathrm{CO}_{2}$ uptake. J. Appl. Physiol. 38: 710-718.

41. Holmes, R. S. 1977. Muscle enzyme purification, molecular properties and ontogeny of carbonic anhydrase isoenzymes. Evidence for $A, B$, and $C$ isoenzymes in avian and mammalian tissues. Eur. J. Biochem. 78: 511520.

42. Koester, M. K., A. M. Register, and E. A. Noltmann. 1977. Basic muscle protein, a third genetic locus isoenzyme of carbonic anhydrase? Biochem. Biophys. Res. Commun. 76: 196-204.

43. Register, A. M., M. K. Koester, and E. A. Noltmann 1978. Discovery of carbonic anhydrase in rabbit skeletal muscle and evidence for its identity with "basic muscle protein." J. Biol. Chem. 253: 4143-4152.

44. Struyvenberg, A., R. B. Morrison, and A. S. Relman. 1968. Acid-base behaviour of separated canine renal tubular cells. Am. J. Physiol. 214: 1155-1162.

45. Biachara, M., M. Paillard, F. Lierd, and J. P. Gardin. 1980. Hydrogen transport in rabbit kidney proximal tubules. $\mathrm{Na}^{+}: \mathrm{H}^{+}$exchange. Am. J. Physiol. 238: F445-451. 